liferative glomerulonephritis, two had total kidney infarction, and one had severe interstitial nephritis with, on biopsy, what appeared to be severe tubular compression. The remaining patient had a combination of extensive tubular blockage due to myeloma protein and glomerulonephritis.

The possible mechanisms underlying the development of these various nephrographic patterns have been recently reviewed (Fry and Cattell, 1972). Space precludes any further discussion of these at this time. It must, however, be reemphasized that the diagnostic value of the nephrographic pattern relates to the changes in density observed with time. Precise measurement of absolute density is difficult, depending as it does on many independent variable factors. In general, doubtful changes in density should be ignored and only unequivocal changes recorded. On no account should a diagnosis be attempted when the urographic technique has resulted in unsatisfactory radiographs.

Though based on relatively small numbers of cases these observations confirm that distinctive nephrographic patterns are observed in patients with acute renal failure. They also indicate that more extensive observations are required both to assess more fully the diagnostic value of the nephrographic pattern and to define more clearly the mechanisms underlying the development of the different patterns.

We would like to record our appreciation of the work of the radiographers responsible for these examinations, especially Miss Jill
Baldock, Miss Anne Casey, and Miss Jane Cooper who were the superintendent radiographers. We would also like to thank Mrs. Sylvia Welsh for her invaluable help throughout the study.

\section{References}

Brown, C. B., Glancy, J. J., Fry, I. K., and Cattell, W. R. (1970). Lancet, 2, 952.

Chamberlain, M. J., and Sherwood, T. (1967). Nephron, 4, 65.

Eliahou, H. E. (1964). British Medical fournal, 1, 807.

Eliahou, H. E., and Bata, A. (1965). Nephron, 2, 287.

Fry, I. K., and Cattell, W. R. (1970). British fournal of Hospital Medicine, 3, 67.

Fry, I. K., and Cattell, W. R. (1971a). British fournal of Radiology, 44, 198.

Fry, I. K., and Cattell, W. R. (1971b). British Medical Bulletin, 27, 148.

Fry, I. K., and Cattell, W. R. (1972). British Medical Bulletin, 28, 227.

Graber, I. G., and Sevitt, S. (1959). Fournal of Clinical Pathology, 12, 25.

Levinsky, N. G. (1966). New England fournal of Medicine, 274, 1016.

Luke, R. G., and Kennedy, A. C. (1967). Postgraduate Medical fournal, 43, 280.

Mahaffy, R. G., Matheson, N. A., and Caridis, D. T. (1969). Clinical Radiology, 20, 320.

Meadows, S. R., Cameron, J. S., Ogg, C. S., and Saxton, H. M. (1971). Archives of Disease in Childhood, 46,221 .

Moseley, I. F., McIntosh, C. S., Fry, I. K., and Cattell, W. R. (1971). Proceedings of the European Dialysis and Transplant Association, 8, 537.

Perlmutter, M., Grossman, S. L., Rothenburg, S., and Dobkin, G. (1959). Fournal of the American Medical Association, 170, 1533.

Platts, M. M. (1966). Clinical Science, 30, 453.

Rosenbaum, J. L. (1967). In Renal Failure, ed. A. N. Brest and G. H. Moyer, p. 253. London, Pitman Medical.

Schencker, B. (1964). Radiology, 83, 12.

Wrong, O. M. (1971). British Medical Bulletin, 27, 97.

\title{
Euglycaemic Diabetic Ketoacidosis
}

\author{
J. F. MUNRO, I. W. CAMPBELL, A. C. MCCUISH, L. J. P. DUNCAN
}

British Medical fournal, 1973, 2, 578-580

\section{Summary}

Of a series of 211 episodes of diabetic metabolic decompensation 37 had severe euglycaemic ketoacidosis (a blood sugar level of less than $300 \mathrm{mg} / 100 \mathrm{ml}$ and a plasma bicarbonate of $10 \mathrm{mEq} / 1$. or less). All were young insulindependent diabetics, only one being previously undiagnosed. Vomiting was a common factor, and in all carbohydrate reduction occurred with continued or increased daily insulin dose. Treatment comprised fluid and electrolyte replacement and large doses of insulin covered by adequate carbohydrate, many receiving $10 \%$ dextrose. Alkali was either withheld or given sparingly and the therapy was monitored by serial estimations of plasma bicarbonate. All the patients survived.

\section{Introduction}

During 1964-71 211 episodes of severe diabetic metabolic decompensation were treated in the general medical wards to which the diabetic department is affiliated. In all, either the

Diabetic Department, Royal Infirmary, Edinburgh EH3 9YW

J. F. MUNRO, M.B., F.R.C.P., Senior Registrar (Now Consultant Physician, Eastern General Hospital, Edinburgh)

I. W. CAMPBELL, M.B., M.R.C.P., Pfizer Research Fellow (Now Registrar) A. C. MCCUISH, M.B., M.R.C.P., Registrar (Now Senior Registrar)

L. J. P. DUNCAN, M.B., F.R.C.P., Consultant Physician blood glucose exceeded $650 \mathrm{mg} / 100 \mathrm{ml}$ or the plasma bicarbonate was less than $15 \mathrm{mEq} / 1$. In 11 there was gross hyperglycaemia and hyperosmolarity but no ketoacidosis (Campbell et al., 1973). This paper considers the other extreme of the broad spectrum of diabetic metabolic decompensation-namely, severe ketoacidosis with a plasma bicarbonate of $10 \mathrm{mEq} / \mathrm{l}$. or less without pronounced hyperglycaemia, the blood glucose being less than $300 \mathrm{mg} / 100 \mathrm{ml}$. We have called this syndrome "euglycaemic diabetic ketoacidosis" for lack of a better term.

\section{Details of Patients}

Thirty-seven episodes of euglycaemic diabetic ketoacidosis occurred in 17 patients, 11 of them female. Twelve presented only once, two had two episodes, another two each had three similar admissions, and one required treatment for this condition on 15 occasions. All were young (average age 18.6 years, range 10-28) and with one exception were known insulindependent diabetics (mean duration six years, range two months15 years). The mean daily insulin dose was 101 I.U. (range 26-300) but in only one patient was it greater than 200 I.U. Before 26 episodes occurred satisfactory control had been obtained by the injection each morning of soluble and protamine zinc insulins, in six an additional evening dose of soluble was required, and in four the treatment was Actrapid combined with either Novo Crystal II or insulin zinc suspension (amorphous) injected twice daily. The only previously undiagnosed diabetic gave a one-month history of thirst and for two days before admission had abdominal pain with frequent vomiting. The mean duration of symptoms, of which vomiting was the 
most frequent, was less than two days (range six hours-eight days) (table I). In four of the five episodes without vomiting

TABLE I-Frequency of Symptoms

\begin{tabular}{|c|c|c|c|c|}
\hline $\begin{array}{l}\text { Vomiting } \\
\text { Abdominal pain } \\
\text { Thirst } \quad \cdots \\
\text { Nausea } \\
\text { Frequency }\end{array}$ & $\begin{array}{l}\ddot{*} \\
\ddot{*}\end{array}$ & $\begin{array}{l}\ddot{*} \\
\ddot{*} \\
\ddot{*}\end{array}$ & $\begin{array}{lr}\because & 32 \\
\because & 10 \\
\therefore & 9 \\
\therefore & 4 \\
\therefore & 4\end{array}$ & 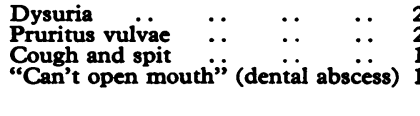 \\
\hline
\end{tabular}

nausea caused reduction in carbohydrate intake, and the other patient stopped eating because of a dental abscess. On 10 occasions the patients continued to take the usual amount of insulin and on 17 they had increased the insulin dosage. In four episodes no precipitating cause was found and psychological stress was thought to be a factor in the patient who had 15 episodes, though he also had a radiologically-proved duodenal ulcer. Five episodes occurred in patients who had made an inappropriate reduction in carbohydrate intake-for example, one had omitted to take school lunches for a week. Three further episodes of poor control occurred during pregnancy; in each case the patient had reduced carbohydrate ingestion in an, attempt to abolish glycosuria. Eight episodes were associated with infection, and two with apparent insulin resistance.

On admission all exhibited air hunger but were conscious and capable of giving a history; in 21 episodes they were fully alert and in 16 drowsy. Dehydration was assessed clinically as being absent on five, minimal on 19, and moderate on 13 occasions, each of the latter being associated with vomiting. None was severely dehydrated and only once was the systolic blood pressure recorded at less than $100 \mathrm{~mm} \mathrm{Hg}$. The mean admission temperature was 97.6 (range 95-99.6 ${ }^{\circ} \mathrm{F}$ ) -36.4 $\left(35-37 \cdot 5^{\circ} \mathrm{C}\right)$. The biochemical findings on admission are shown in table II. On seven occasions the initial blood glucose was less than $100 \mathrm{mg} / 100 \mathrm{ml}$, and in a further nine was less than 200 $\mathrm{mg} / 100 \mathrm{ml}$. Retrogression analysis showed no statistically significant relation between bicarbonate and either the potassium or blood glucose levels. Arterial $\mathrm{pH}$ was not routinely measured, but in two episodes with a bicarbonate of less than $5 \mathrm{mEq} / \mathrm{l}$. it was recorded as less than 7.00 .

\section{Management}

Four episodes occurring in the same patient were treated without intravenous fluid, vomiting being controlled by cyclizine, carbohydrate being given one or two-hourly as 25-30 g glucose drinks in milk and insulin subcutaneously three to four-hourly until the bicarbonate had risen to a satisfactory level $(18 \mathrm{mEq} / \mathrm{l}$. or more). Potassium supplements were taken orally.

The other episodes were treated by intravenous infusion. The mean and range of replacement therapy given during the first 24 hours is summarized in table III. In 12 episodes, occurring in four patients, bicarbonate was also given in aliquots of $25 \mathrm{mEq}$ in $500 \mathrm{ml}$ of a dextrose solution (mean $60 \mathrm{mEq}$, range $25-150 \mathrm{mEq}$ ). Alkali was not administered in the other 21 episodes. All the patients survived; the biochemical data after 24 hours of treatment are summarized in table IV.

\section{Discussion}

The usually recognized features of severe diabetic metabolic decompensation are considerable hyperglycaemia and metabolic ketoacidosis. These need not develop either consequentially or simultaneously nor parallel each other in severity (Duncan, 1971). Though a blood glucose of less than $300 \mathrm{mg} / 100 \mathrm{ml}$ was not recorded in a series of 100 patients with diabetic ketoacidosis (Sheldon and Pyke, 1968), severe ketoacidosis without pronounced hyperglycaemia can occur in insulin-dependent diabetics subjected to ketogenic stress and who are unable to take sufficient carbohydrate by mouth but continue to take insulin, often in increased dosage. The latter prevents undue gluconeogenesis and facilitates the cellular utilization of the limited amount of glucose available until the ketoacidosis and increase in free fatty acids cause insulin resistance, thereby preventing subjective hypoglycaemia in the continuing absence of carbohydrate ingestion. In our experience this biochemical chain of events can develop rapidly but the mechanism is obscure. The frequent association with vomiting would suggest that vomiting itself may be a cause, aggravating factor, and a consequence of the metabolic acidosis. The possibility of renal tubular acidosis was considered in the three patients who had several episodes. A Wrong and Davies acidification test showed that they were

TABLE II-Mean and Range of Biochemical Details on Admission Related to Initial Blood Glucose

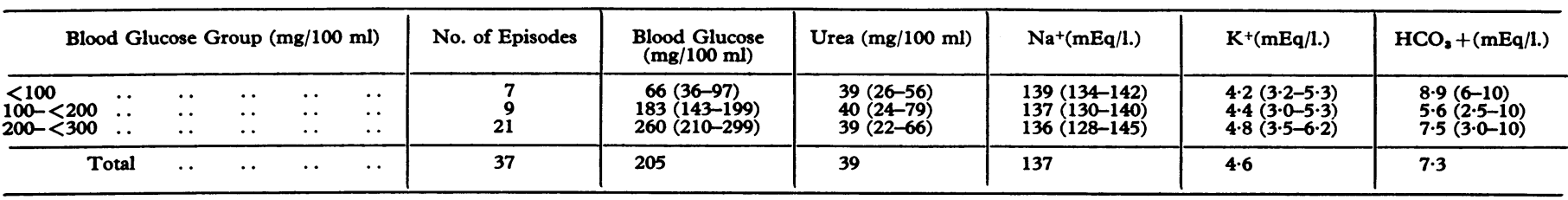

TABLE III-Mean and Range of Intravenous Therapy during First 24 Hours Related to Initial Blood Glucose

\begin{tabular}{|c|c|c|c|c|c|c|c|c|c|c|}
\hline \multicolumn{3}{|c|}{$\begin{array}{c}\text { Blood Glucose Group } \\
(\mathrm{mg} / 100 \mathrm{ml})\end{array}$} & \multirow{2}{*}{$\begin{array}{c}\begin{array}{c}\text { No. of } \\
\text { Episodes }\end{array} \\
5^{*} \\
9 \\
19+\end{array}$} & \multirow{2}{*}{$\begin{array}{l}\begin{array}{c}\text { Soluble } \\
\text { Insulin } \\
\text { (I.U.) }\end{array} \\
260(126-310) \\
516(112-1,280) \\
399(166-749)\end{array}$} & \multirow{2}{*}{$\begin{array}{c}\begin{array}{c}\text { Potassium } \\
(\mathrm{mEq})\end{array} \\
102(84-130) \\
155(58-351) \\
143(26-319)\end{array}$} & \multirow{2}{*}{$\begin{array}{l}\begin{array}{l}\text { Total Fluid } \\
(1 .)\end{array} \\
4 \cdot 2(3 \cdot 0-5 \cdot 0) \\
5 \cdot 9(4 \cdot 0-10 \cdot 0) \\
4 \cdot 9(3 \cdot 0-7 \cdot 5)\end{array}$} & \multirow{2}{*}{\begin{tabular}{l}
\multicolumn{1}{c}{$\begin{array}{c}\text { N-saline } \\
(1 .)\end{array}$} \\
0 \\
$0.9(0-2.0)$ \\
$0.6(0-1.5)$
\end{tabular}} & \multirow{2}{*}{$\begin{array}{c}\begin{array}{c}5 \% \\
\text { saline } \\
\text { (1.) }\end{array} \\
1.4(0 \cdot 5-2 \cdot 0) \\
1.3(0 \cdot 5-2 \cdot 0) \\
1.0(0-2 \cdot 0)\end{array}$} & \multirow{2}{*}{$\begin{array}{c}5 \% \text { Dextrose } \\
(1 .)\end{array}$} & \multirow{2}{*}{$\begin{array}{c}10 \% \text { Dextrose } \\
(1 .)\end{array}$} \\
\hline $\begin{array}{l}<100 \\
100-<200 \\
200-<300\end{array}$ & $\because$ & $\begin{array}{l}\cdots \\
\cdots\end{array}$ & & & & & & & & \\
\hline Total & .. & $\ldots$ & 33 & $410(112-1,280)$ & $140(26-351)$ & $5 \cdot 1(3.0-10.0)$ & $0.6(0-2.0)$ & $1 \cdot 2(0-2 \cdot 0)$ & $2.0(0.5-5.0)$ & $1.3(0-3.5)$ \\
\hline
\end{tabular}

*Excludes two episodes treated orally.

†Excludes two episodes treated orally.

TABLE IV-Mean and Range of Biochemical Details after 24 Hours Related to Initial Blood Glucose

\begin{tabular}{|c|c|c|c|c|c|c|c|c|c|c|}
\hline \multicolumn{5}{|c|}{$\begin{array}{l}\text { Blood Glucose Group } \\
(\mathrm{mg} / 100 \mathrm{ml})\end{array}$} & $\begin{array}{c}\text { No. of } \\
\text { Episodes }\end{array}$ & $\begin{array}{l}\text { Blood Glucose } \\
(\mathrm{mg} / 100 \mathrm{ml})\end{array}$ & $\begin{array}{c}\text { Urea } \\
(\mathbf{m g} / 100 \mathrm{ml})\end{array}$ & $\mathrm{Na}^{+}(\mathrm{mEq} / \mathrm{l})$. & $\mathrm{K}^{+}(\mathrm{mEq} / \mathbf{l})$. & $\mathrm{HCO}_{3}+(\mathrm{mEq} / \mathrm{l})$. \\
\hline $\begin{array}{l}<100 \\
100-<200 \\
200-<300\end{array}$ & $\begin{array}{l}\because \\
\cdots \\
.\end{array}$ & $\begin{array}{l}\cdots \\
\cdots\end{array}$ & $\begin{array}{l}\because \\
\cdots\end{array}$ & $\begin{array}{l}\cdots \\
\cdots\end{array}$ & $\begin{array}{r}7 \\
9 \\
21\end{array}$ & $\begin{array}{l}178(115-280) \\
121(55-260) \\
156(60-282)\end{array}$ & $\begin{array}{l}25(17-38) \\
22(14-32) \\
25(12-44)\end{array}$ & $\begin{array}{l}135(130-139) \\
140(137-145) \\
135(130-142)\end{array}$ & $\begin{array}{l}3.7(3.1-4.0) \\
3.8(3.1-4.6) \\
3.9(3.2-4.9)\end{array}$ & $\begin{array}{l}20 \cdot 4(18-26 \cdot 5) \\
19 \cdot 1(13-23) \\
19 \cdot 7(14-24 \cdot 5)\end{array}$ \\
\hline Tota & & .. & .. & .. & 37 & 152 & 24 & 137 & 3.8 & 19.6 \\
\hline
\end{tabular}


unable to acidify their urine a few days after aamission in "euglycaemic ketoacidosis" but more formal studies performed when they were metabolically stable failed to show any defect of $\mathrm{H}^{+}$and $\mathrm{NH}^{+}$excretion. Whatever the aetiology, the young age of the patients suggests an ability to "grow out" of the tendency.

The patients' mental alertness and in most their ability to walk into hospital, even when severely ketoacidotic, supports the concept that clouding of consciousness is unrelated to the severity of the ketoacidosis but is dependent on severe hyperglycaemia and hyperosmolarity (Gerich et al., 1971).

The principles of treatment are to correct fluid and electrolyte loss and to re-establish carbohydrate metabolism. The former is often trivial, resulting largely from the vomiting, but because of the latter intravenous therapy with modest quantities of potassium, sodium, and water is usually required. Nevertheless, sufficient exogenous glucose must also be given to restore normal cellular utilization and thus reverse the ketoacidosis. Normal saline should therefore be avoided and dehydration corrected with $5 \%$ dextrose/saline and $5 \%$ dextrose. When the blood glucose is low in the absence of clinical dehydration $10 \%$ dextrose may be required. It has been recommended that the dose of insulin should be proportional to the blood glucose level (Sheldon and Pyke, 1968) but this is clearly inappropriate in these "euglycaemic" patients who may require large quantities of insulin to correct their severe ketoacidosis. Response to therapy is assessed very largely by the serum bicarbonate which after four to five hours should begin to rise fairly rapidly, irrespective of whether or not bicarbonate has been administered.

Though the liberal use of bicarbonate has been recommended
(Addis et al., 1964) others have suggested a more cautious approach (Zimmet et al., 1970). We avoided giving bicarbonate except in those patients with recurrent admission in whom we suspected there could be a renal tubular dysfunction. By correcting the extracellular acidosis without influencing the causal inadequate cellular utilization of glucose, the excessive use of alkali may produce injurious disequilibrium between the intracellular and extracellular pH (Posner and Plum, 1967).

The department's policy of encouraging diabetics to adjust their own dose of insulin may, in part, be responsible for our not uncommon experience of euglycaemic ketoacidosis, which has previously attracted very little attention. These patients form one end of the broad spectrum of diabetic metabolic decompensation but are of therapeutic importance because with appropriate management biochemical death should not occur.

\section{References}

Addis, G. J., Thomson, W. S. T., and Welch, J. D. (1964). Lancet, 2, 223. Campbell, I. W., Munro, J. F., and Duncan, L. J. P. (1973). In press.

Duncan, L. J. P. (1971). In Textbook of Medical Treatment, ed. S. Alstead, A. G. McGregor, and R. H. Girdwood, 12th edn. p. 334. Edinburgh, Churchill Livingstone.

Gerich, J. E., Martin, M. M., and Recent, L. (1971). Diabetes, 20, 228.

Posner, J. B., and Plum, F. (1967). New England fournal of Medicine, 227,

Sheldon, J., and Pyke, D. A. (1968). In Clinical Diabetes and its Biochemical Basis, ed. W. G. Oakley, D. A. Pyke, and K. W. Taylor. Chapt. 17. Oxford, Blackwell Scientific.

Zimmet, P. Z., Taft, P., Ennis, G. C., and Sheath, J. (1970). British Medical Fournal, 3, 610 .

\title{
Hand Carriage of Gram-negative Bacilli and Staphylococcus aureus
}

\author{
JOHAN N. BRUUN, CLAUS O. SOLBERG
}

British Medical fournal, 1973, 2, 580-582

\section{Summary}

The influence of hexachlorophane disinfection on the bacterial hand flora of hospital personnel has been examined. Hexachlorophane effectively reduced the total number of bacteria and the staphylococcal carriage. Gram-negative bacilli were isolated from $18.8 \%$ of the personnel, and $13 \%$ of the carriers continued to carry Gram-negative bacilli for more than six months. The carrier rate was significantly higher among those using hexachlorophane detergents $(20.8 \%)$ than among those using plain soap (14.1\%). Prolonged hand carriage of Gram-negative bacilli was often associated with skin irritation, especially of the nailfolds. Hand carriage may be an important source of Gram-negative infections in hospital, and the increase in these infections may partly be due to extensive use of hexachlorophane preparations.

University of Bergen, School of Medicine, Medical Department B, N-5000 Bergen, Norway

JOHAN N. BRUUN, M.D., Assistant Physician

CLAUS O. SOLBERG, M.D., Associate Professor of Medicine

\section{Introduction}

Infections acquired in hospitals are usually caused by Gramnegative bacilli or Staphylococcus aureus (Adler et al., 1971; Williams et al., 1966), and transmission by the hands of hospital personnel is regarded as one of the most important routes of cross-infection (Juhlin and Ericson, 1965; Mortimer et al., 1966; Salzman et al., 1968; Adler et al., 1970). Previously we documented that treatment of surgical patients and personnel with hexachlorophane containing detergents effectively reduced the transmission of staphylococci and the prevalence of postoperative staphylococcal infections (Bruun, 1970). In nurseries, however, the extensive use of these preparations has been incriminated as the cause of increasing Gram-negative bacillary infections (Forfar et al., 1968; Light et al., 1968).

In the present study it was shown that a significant number of hospital personnel carried Gram-negative bacilli on their hands. The duration of this carriage and the effect of long-term use of a hexachlorophane detergent on the bacterial hand flora are reported.

\section{Material and Methods}

The bacterial hand flora of the ward personnel (nurses and nurses' aides) in three departments at Haukeland Hospital, Bergen, Norway, was examined. Samples were obtained during two periods with six-months in between. During each period 